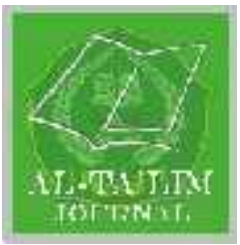

AL-TA'LIM JOURNAL, 23 (3), 2016, (214-223)

(Print ISSN 1410-7546 Online ISSN 2355-7893)

Available online at http://journal.tarbiyahiainib.ac.id/index.php/attalim

\title{
The Effectiveness of Premarital Counseling Service on the Harmony of Marriage in Family Resilience
}

\author{
Received: $14^{\text {th }}$ Agustus 2016; Revised: $14^{\text {th }}$ September 2016; Accepted: $19^{\text {th }}$ November 2016 \\ Permalink/DOI: http://dx.doi.org/10.15548/jt.v23i3.254
}

\author{
Duski Samad*) \\ Institut Agama Islam Negeri Imam Bonjol \\ Padang, Indonesia \\ E-mail: duskisamad60@gmail.com
}

\section{Remiswal}

Institut Agama Islam Negeri Imam Bonjol Padang, Indonesia

E-mail: remremiswal1971@yahoo.co.id

\section{Gusril Kenedi}

Institut Agama Islam Negeri Imam Bonjol Padang, Indonesia

E-mail: gusrilkenedi1965@gmail.com

\section{Mujahidil Mustaqim}

Pusat Studi Pendidikan dan Humanitas Institut Agama Islam Negeri Imam Bonjol Padang, Indonesia

E-mail:

mujahidil.mustaqim@student.upi.edu

\begin{abstract}
The hypothesis of preliminary research stated that the high rate of divorcement in West Sumatera was caused by the weakness of the role and function of Badan Penasihatan Pembinaan dan Pelestarian Perkawinan (Board of Marriage Advisory and Preservation) or BP4 in every district in providing premarital counseling service, thus prospective couples have not enough marital knowledge to work on their households. The aim of the research is to reveal the effectiveness of premarital counseling service on the harmony of marriage in realizing family resilience in West Sumatera.The research applied the mixed research method by using sequential explanatory design model. The research object included first, the prospective husbands/wives who had been provided premarital counseling service by the BP4 in West Sumatera, and second, the coaches and counselors of the BP4 premarital counseling service in West Sumatera.The results showed that, first, the effectiveness of premarital counseling service on the harmony of marriage reached as high as 3\% in Pariaman, and as low as $0.1 \%$ in Pesisir Selatan; second, the effectiveness of premarital counseling service on family resilience had as high as $4.5 \%$ in Lima Puluh Kota district, and as low as $0.1 \%$ in Pesisir Selatan; and third, the role of the BP4 in West Sumatera was, in fact, very low.
\end{abstract}

*) Corresponding Author

Keywords: Premarital counseling service, harmony of marriage, family resilience

How to Cite: Samad, D., Remiswal, r., Kenedi, G., \& Mustaqim, M. (2016). The effectiveness of premarital counseling service on the harmony of marriage in family resilience. Al-Ta Lim Journal, 23(3). doi: http://dx.doi.org/10.15548/jt.v23i3.254

\section{INTRODUCTION}

Family resilience is an indicator to measure the development of demography. Family resilience is the capability of a family in performing its functions. There are eight functions of a family which must be empowered including religious, love and affection, protection, socio-cultural, reproductive health, education, economic, and environmental protection functions.
The harmony of marriage is the requirement to realize those family functions. This is because having a harmonious marriage is the desire of any married couple in their household. Harmonious household can maintain the eternity of the couple's love till the end of their life. Although a harmonious marriage is not impossible to realize, it still requires a great effort and understanding from each other. 
The realization of harmony and disharmony of any household does not only involve a single variable, but many also take part in it such as psychological, social, and economic factors, among others. Psychologically, the experiences during an individual's developmental process have some effects on the marriage concept. The development of any individual from prenatal, infancy, childhood, adolescent, adulthood, to old age provides different meanings for the marriage concept.

West Sumatera, known by its philosophy "adat basandi syara', syara' basandi kitabullah" has been surprised by the increase of the divorcement rate. The increase was reported in a statement of the head of the BP4 of West Sumatera, Asasriwarni. He said that divorces proposed by wives reached 3.684 cases and divorces proposed by husbands were 1.742 cases, making up to a total of 5.426 cases. On the other hand, in 2003 West Sumatera had only 333 cases registered in the religious courts. It means that in the 10-year period, the divorcement cases had increased almost 20\% (the exact figure was $18 \%$ ). The data described how the bond of marriage was quite weak in West Sumatera.

In addition, the result of the research conducted by Kenedi (2005) on Minangkabau-ethnic students found that the students tended to suffer from confusion in facing their prospective marriage (Kenedi, 2005). On the other side, from the preliminary research conducted in several religious affairs offices, it was found that the guidance or course for prospective marriage partners, called screening, held by the officers was not held very well, especially in terms of the speakers' competence, the relevance of the topics, and the availability of time.

On the other hand, BKKBN as a government institution administers the duties of the government in terms of the family planning and prosperity as set by the laws. The duties are (a) formulating and administering certain activities in family planning and prosperity; and, (b) formulating the guidance of developing family quality.

The marriage which is considered as the sacred thing regardless the ethnicity, culture, or religion is depraved with too many short-term marriages. The divorcement case happening in West Sumatera indicates a lot of things. First, the marriage recommended highly in Islam because of its benefits has not been experienced well by the marriage couples. On the contrary, they received the mudharat or bad benefits as well as the wrath of Allah. Second, the adulthood developmental tasks are not carried out well. Furthermore, the couples were not able to solve some causes of marriage disharmony or divorcement.

In fact, Islam teaches that in marriage, Muslims can understand the wisdom of God in terms of the creation of their own partner who are suitable for each other, so they can fulfill their natural needs (soul, mind, and physical) and be peaceful, calm, and get the feelings of completing each other as well as have the love and affection (Quthub, 2014).

Therefore, Islam greatly concerns on the formation of family with the sakinah mawaddah wa rahmah concept: the family is built following the values of Islam as the religion. A family built under the basis of the religion can survive and last long. Being divorced, although allowed in Islam, is still the most hated occurrence before Allah.

According to various aforementioned results of studies about marriage, the integrity and happiness which can be realized by the husband/wife are mostly determined by how far the readiness and provision possessed by those prospective couples prior to stepping into marriage life. The readiness and provision include knowledge and understanding about the roles, tasks and obligation of husbands and wives, the abilities or skills in adjusting with the partner, the big family, and the changes, and the skills to solve marriage's problems or conflict. To ensure such preparedness for the prospective 
husband/wife, the BP4 has the role and task to give the optimal provision.

Dealing with this issue, Murray (2005) elaborate the need for marriage and family counselors to undertake prevention. Premarital counseling is a widely implemented prevention activity that is aimed at enhancing marital relationships.

The ability to predict marital success has become increasingly important given the high divorce rates of the last 2 decades. Several recent longitudinal studies have attempted to pinpoint the factors that are predictive of marital success (Larsen \& Olson, 1989).

From above discussions, this research explored further premarital counseling service on the harmony of marriage in realizing family resilience in West Sumatra. The results are hoped to be helpful for the BKKBN and the BP4 in improving premarital counseling service so that the prospective husband/wife can realize their family's desire to be sakinah mawaddah warahmah.

The question posed in this research is "how effective was premarital counseling service on the harmony of marriage in realizing the family resilience in West Sumatera?" The scopes of the problem include first, the effectiveness of premarital counseling service on the harmony of marriage in West Sumatera, second, the effectiveness of premarital counseling service on family resilience in West Sumatera, and third, the type of premarital counseling service provided in the BP4 in West Sumatera.

\section{METHOD}

This was field research. The method used was mixed research method. The method refers to the combination of qualitative method and quantitative method used in a study in order to get more comprehensive, valid, reliable, and objective data (Sugiyono, 2014).
The design used was sequential explanatory design. The design is characterized by collecting and analyzing the quantitative data at the first phase, and then followed by collecting and analyzing the qualitative data at the second phase to strengthen the results of the quantitative method done at the first phase (Sugiyono, 2014).

The research objects included first, the prospective husbands/wives given premarital counseling service by the BP4 of West Sumatera, and second, the coaches and counselors of premarital counseling service at the BP4 of West Sumatra. The sample included five cities/districts in West Sumatra, i.e. Padang, Pariaman, Pesisir Selatan, Tanah Datar, and Lima Puluh Kota.

Data collection techniques were questionnaire, interview, observation and documentation. The data were then analyzed quantitatively by using multiple linear regressions, and qualitatively by using Miles and Huberman technique.

\section{RESULT AND DISCUSSION}

The results found in this research are described as follow:

1. The Effectiveness of Premarital Counseling Service on the Harmony of Marriage in West Sumatera.

a. The effectiveness of premarital counseling service on the harmony of marriage in Padang.

The effectiveness rate of premarital counseling service on the harmony of marriage in Padang can be seen in the following:

Table 1. Model Summary Table.

\begin{tabular}{lcccc}
\hline \multicolumn{4}{c}{ Model Summary } \\
\hline Model & $\mathrm{R}$ & $\mathrm{R}$ & $\begin{array}{c}\text { Adjusted } \\
\text { Square }\end{array}$ & $\begin{array}{c}\text { R Std. Error of the } \\
\text { Estimate }\end{array}$ \\
\hline 1 & $.098^{\mathrm{a}}$ & .010 & .000 & 16.208 \\
\hline a. Predictors: (Constant), counseling \\
b. Dependent Variable: harmony
\end{tabular}


The effectiveness rate is described in coefficient of $r$ square of 0.010 or $1 \%(\mathrm{KD}=\mathrm{R} \times 100 \%)$. The rate of the effectiveness of premarital counseling service on the harmony of marriage in Padang is considered very low. However, the rate shows that Ha is accepted and Ho is rejected. It means there is a significant influence of premarital counseling service towards the harmony of marriage in Padang.

b. The effectiveness of premarital counseling service on the harmony of marriage in Pariaman.

The effectiveness rate of premarital counseling service on the harmony of marriage in Pariaman can be seen in the following:

Table 2. Model Summary Table

\begin{tabular}{|c|c|c|c|c|}
\hline \multicolumn{5}{|c|}{ Model Summary ${ }^{\mathrm{b}}$} \\
\hline Model & $\mathrm{R}$ & $\begin{array}{c}\mathrm{R} \\
\text { Square }\end{array}$ & $\begin{array}{l}\text { Adjusted } \\
\text { R Square }\end{array}$ & $\begin{array}{l}\text { Std. Error of } \\
\text { the Estimate }\end{array}$ \\
\hline 1 & $.174^{\mathrm{a}}$ & .030 & .020 & 16.093 \\
\hline
\end{tabular}

a. Predictors: (Constant), Counseling

b. Dependent Variable: Harmony

The effectiveness rate is shown by the $R$ Square of 0.030 or $3 \%(\mathrm{KD}=\mathrm{R} \times 100 \%)$. The effectiveness rate in Pariaman is also considered very low. However, the rate means that $\mathrm{Ha}$ is accepted and $\mathrm{Ho}$ is rejected. Thus, there is a significant influence of premarital counseling service towards the harmony of marriage in Pariaman.

c. The effectiveness of premarital counseling service on the harmony of marriage in Pesisir Selatan.

Below is the model summary table for the effectiveness of premarital counseling service on the harmony of marriage in Pesisir Selatan.
Table 3. Model Summary Table

\begin{tabular}{lrrrr}
\multicolumn{5}{c}{ Model Summary $^{\mathrm{b}}$} \\
\hline Model & $\mathrm{R}$ & $\mathrm{R}$ & $\begin{array}{c}\text { Adjusted } \\
\text { R Square }\end{array}$ & $\begin{array}{l}\text { Std. Error of } \\
\text { the Estimate }\end{array}$ \\
\hline 1 & $.031^{\mathrm{a}}$ & .001 & -.009 & 12.462 \\
\hline
\end{tabular}

a. Predictors: (Constant), counseling

b. Dependent Variable: harmony

The effectiveness rate is shown by the $R$ Square of 0.001 or $0.1 \%(\mathrm{KD}=\mathrm{R} \times 100 \%)$. The effectiveness rate is also considered very low here. However, the rate means that $\mathrm{Ha}$ is accepted and $\mathrm{Ho}$ is rejected. Thus, there is a significant influence of premarital counseling service towards the harmony of marriage in Pesisir Selatan.

d. The effectiveness of premarital counseling service on the harmony of marriage in Tanah Datar.

The rate of effectiveness of premarital counseling service on the harmony of marriage in Tanah Datar can be seen in below model summary table.

Table 4. Model Summary Table

\begin{tabular}{|c|c|c|c|c|}
\hline \multicolumn{5}{|c|}{ Model Summary } \\
\hline Model & $\mathrm{R}$ & $\mathrm{R}$ & Adjusted & Std. Error of \\
\hline & & Square & R Square & the Estimate \\
\hline 1 & $.060^{\mathrm{a}}$ & .004 & -.007 & 16.560 \\
\hline
\end{tabular}

a. Predictors: (Constant), Counseling

b. Dependent Variable: Harmony

The rate of effectiveness ( $\mathrm{r}$ square) is 0.004 or $0.4 \%(\mathrm{KD}=\mathrm{R} \times$ $100 \%)$. Similarly, the effectiveness rate is quite low in Tanah Datar. In this case, $\mathrm{Ha}$ is accepted and $\mathrm{Ho}$ is rejected. To conclude, there is also a significant influence of premarital counseling service towards the harmony of marriage in Tanah Datar. 
e. The effectiveness of premarital counseling service on the harmony of marriage in Lima Puluh Kota.

The following model summary table shows the rate of effectiveness of premarital counseling service on the harmony of marriage in Lima Puluh Kota.

Table 5. Model Summary Table

\begin{tabular}{lrrrr}
\multicolumn{5}{c}{ Model Summary $^{\mathrm{b}}$} \\
\hline Model & $\mathrm{R}$ & $\mathrm{R}$ & $\begin{array}{l}\text { Adjusted } \\
\text { R Square }\end{array}$ & $\begin{array}{l}\text { Std. Error of } \\
\text { the Estimate }\end{array}$ \\
\hline 1 & & Square & R Squ \\
\hline
\end{tabular}

a. Predictors: (Constant), Counseling

b. Dependent Variable: Harmony

The rate of effectiveness $(R$ Square) is 0.012 or $1.2 \%(\mathrm{KD}=\mathrm{R} \mathrm{x}$ $100 \%)$. The rate of effectiveness is also low in Lima Puluh Kota. Here, $\mathrm{Ha}$ is accepted and Ho is rejected. It means that there is a significant influence of premarital counseling service towards the harmony of marriage in Lima Puluh Kota.

2. The Effectiveness of Premarital Counseling Service on Family Resilience in West Sumatera.

a. The effectiveness of premarital counseling service on family resilience in Padang

The rate of effectiveness of premarital counseling service on family resilience in Padang can be seen in below model summary table.

Table 6. Model Summary Table

\begin{tabular}{lrrrr} 
& \multicolumn{4}{c}{ Model Summary } \\
\hline Model & $\mathrm{R}$ & $\mathrm{R}$ & $\begin{array}{r}\text { Adjusted } \\
\text { R }\end{array}$ & $\begin{array}{r}\text { Std. Error of } \\
\text { Square }\end{array}$ \\
& & R Square & the Estimate \\
\hline 1 & $.153^{\mathrm{a}}$ & .023 & .013 & 12.247 \\
\hline
\end{tabular}

a. Predictors: (Constant), counseling

b. Dependent Variable: resilience
As depicted, the rate of effectiveness ( $R$ Square) is 0.023 or $2.3 \%(\mathrm{KD}=\mathrm{R} \times 100 \%)$. The rate of effectiveness of premarital counseling service on family resilience in Padang is considered very low. Here, Ha is accepted and $\mathrm{Ho}$ is rejected. Thus, there is a significant influence of premarital counseling service towards family resilience in Padang.

b. The effectiveness of premarital counseling service on family resilience in Pariaman.

The rate of effectiveness can be seen in below model summary table.

Table 7. Model Summary Table

\begin{tabular}{lccrr}
\multicolumn{4}{c}{ Model Summary } \\
\hline Model & $\mathrm{R}$ & $\begin{array}{c}\mathrm{R} \\
\text { Square }\end{array}$ & $\begin{array}{c}\text { Adjusted } \\
\text { R Square }\end{array}$ & $\begin{array}{r}\text { Std. Error of } \\
\text { the Estimate }\end{array}$ \\
\hline 1 & $.102^{\mathrm{a}}$ & .010 & .000 & 12.070 \\
\hline a. Predictors: (Constant), counseling & \\
b. Dependent Variable: resilience &
\end{tabular}

The rate of effectiveness $(R$ Square) is 0.010 or $1 \%(\mathrm{KD}=\mathrm{R} \times$ $100 \%)$. Similarly, the effectiveness rate of premarital counseling service on family resilience in Pariaman is also considered very low. Also, $\mathrm{Ha}$ is accepted and Ho is rejected. It means that there is a significant influence of premarital counseling service towards family resilience in Pariaman.

c. The effectiveness of premarital counseling service on family resilience in Pesisir Selatan

The rate of effectiveness can be seen in below model summary table.

Table 8. Model Summary Table

\begin{tabular}{lrrrr}
\multicolumn{4}{c}{ Model Summary } \\
\hline Model & $\mathrm{R}$ & $\begin{array}{c}\mathrm{R} \\
\text { Square }\end{array}$ & $\begin{array}{c}\text { Adjusted } \\
\text { R Square }\end{array}$ & $\begin{array}{l}\text { Std. Error of } \\
\text { the Estimate }\end{array}$ \\
\hline 1 & $.036^{\mathrm{a}}$ & .001 & -.009 & 12.512 \\
\hline $\begin{array}{l}\text { a. Predictors: (Constant), counseling } \\
\text { b. Dependent Variable: resilience }\end{array}$ &
\end{tabular}


The rate of effectiveness $(R$ Square) is 0.001 or $0.1 \%(\mathrm{KD}=\mathrm{R} \times$ $100 \%)$. The effectiveness rate of premarital counseling service on family resilience in Pesisir Selatan is also considered very low. Here, $\mathrm{Ha}$ is accepted and Ho is rejected. Therefore, there is a significant influence of premarital counseling service towards family resilience in Pesisir Selatan.

d. The effectiveness of premarital counseling service on family resilience in Tanah Datar.

The rate of effectiveness can be seen in below model summary table.

Table 9. Model Summary Table

\begin{tabular}{|c|c|c|c|c|}
\hline \multicolumn{5}{|c|}{ Model Summary ${ }^{B}$} \\
\hline Model & $\mathrm{R}$ & $\begin{array}{c}\mathrm{R} \\
\text { Square }\end{array}$ & $\begin{array}{l}\text { Adjusted } \\
\text { R Square }\end{array}$ & $\begin{array}{l}\text { Std. Error of } \\
\text { the Estimate }\end{array}$ \\
\hline 1 & $.070^{\mathrm{a}}$ & .005 & -.005 & 19.269 \\
\hline
\end{tabular}

Here, the effectiveness rate $(R$ Square) is 0.005 or $0.5 \%$ ( $\mathrm{KD}=\mathrm{R} \times$ $100 \%)$. However, the effectiveness rate of premarital counseling service on family resilience in Tanah Datar is still considered very low. Then, $\mathrm{Ha}$ is accepted and Ho is rejected. It means there is a significant influence of premarital counseling service towards family resilience in Tanah Datar.

e. The effectiveness of premarital counseling service on family resilience in Lima Puluh Kota.

The rate of effectiveness can be seen in below model summary table.

Table 10. Model Summary Table

\begin{tabular}{lrrrr}
\multicolumn{4}{c}{ Model Summary } \\
\hline Model & $\mathrm{R}$ & $\mathrm{R}$ & $\begin{array}{c}\text { Adjusted } \\
\text { Square }\end{array}$ & $\begin{array}{r}\text { R Square } \\
\text { the Estimate }\end{array}$ \\
\hline 1 & $.213^{\mathrm{a}}$ & .045 & .036 & 16.938 \\
\hline a. Predictors: (Constant), counseling & \\
b. Dependent Variable: resilience
\end{tabular}

In this case, the rate of effectiveness ( $R$ Square) is 0.045 or $4.5 \%$ $(\mathrm{KD}=\mathrm{R} \times 100 \%)$. Still, the effectiveness rate of premarital counseling service on family resilience in Lima Puluh Kota is quite low. Here, Ha is accepted and Ho is rejected. In other words, there is a significant influence of premarital counseling service towards family resilience in Lima Puluh Kota.

3. The Types of Premarital Counseling Service in the Board of Advisory and Preservation of Marriage (BP4) in West Sumatera

a. The roles of the BP4 in providing premarital marriage service for the prospective husband/wife in Pariaman.

The types of the BP4 roles can be reviewed through the characteristics of the BP4 in Pariaman. The characteristics were obtained by interviewing the stakeholders and observing the research field.

1) The Legal Standing and Position of BP4 is Clear

It was interesting to find that the BP4 of Pariaman has had very clear characteristics compared to the other cities or districts in West Sumatera. The BP4 has clear legal standing, position, main duties, and functions. It was stated in the circular letter of Pariaman's Mayor on the legal standing and position of the BP4 of Pariaman. It is clear that there is legal protection from the local government on the BP4 even though the legal protection is only in the form of the circular letter of the Mayor, not yet in the Regional Regulation.

The Mayor's circular letter has several advantages, one of which is the separation of the main functions and duties of the KUA (religious affairs office) and the 
BP4, with the BP4 having its own office building.

2) Materials and counselors of the counseling service are varied depending on the needs of the prospective husband/wife.

If we look at the needs analysis of the prospective husband/wife, the material comprehensiveness of premarital counseling service in Pariaman is complete enough. It means the couple has got various materials, not just from one aspect. For more clear descriptions, it can be seen in the below table:

Table 11. The Materials of Premarital Counseling Service in Pariaman

\begin{tabular}{|c|c|c|}
\hline $\mathrm{NO}$ & Material & Speaker \\
\hline 1 & Marriage Laws & $\begin{array}{l}\text { Drs. H. firtrison Effendi } \\
\text { (BP4 of Pariaman) }\end{array}$ \\
\hline 2 & $\begin{array}{l}\text { The Law on the } \\
\text { Abolition of } \\
\text { Domestic } \\
\text { Violence and } \\
\text { the Children } \\
\text { Protection }\end{array}$ & $\begin{array}{l}\text { H. Bakhtiar Sultan Dt. } \\
\text { Panyali (BP4 of Pariaman) }\end{array}$ \\
\hline 3 & $\begin{array}{l}\text { Fiqih } \\
\text { Munaqahat } \\
\text { (Sharia Law for } \\
\text { Marriage and } \\
\text { Family) }\end{array}$ & $\begin{array}{l}\text { H. Zulkifli Zakaria (MUI } \\
\text { of Pariaman) }\end{array}$ \\
\hline 4 & $\begin{array}{l}\text { The Rights and } \\
\text { Obligations of } \\
\text { Wife }\end{array}$ & $\begin{array}{l}\text { Adi Eka Putra, S.Pd.I } \\
\text { (Pensioner of Religious } \\
\text { Affairs Ministry) }\end{array}$ \\
\hline 5 & $\begin{array}{l}\text { Psychology of } \\
\text { Marriage and } \\
\text { Family }\end{array}$ & $\begin{array}{l}\text { Afrinaldi, MA (Lecturer } \\
\text { of IAIN Bukittinggi) }\end{array}$ \\
\hline 6 & $\begin{array}{l}\text { Religious } \\
\text { Education in } \\
\text { Family }\end{array}$ & $\begin{array}{l}\text { Dra. Endrawati } \\
\text { (Educational Practitioner) }\end{array}$ \\
\hline 7 & $\begin{array}{l}\text { Empowering } \\
\text { Family's } \\
\text { Economy }\end{array}$ & $\begin{array}{l}\text { Drs. H. Khaidir AS (BAZ } \\
\text { of Pariama) }\end{array}$ \\
\hline 8 & $\begin{array}{l}\text { The Role of } \\
\text { Customs in } \\
\text { Empowering } \\
\text { Family }\end{array}$ & $\begin{array}{l}\text { Ali Safar Rajo Nuanso } \\
\text { (LKAAM of Pariaman ) }\end{array}$ \\
\hline 9 & $\begin{array}{l}\text { Clean and } \\
\text { Healthy } \\
\text { Lifestyle }\end{array}$ & $\begin{array}{l}\text { Drs. Yutiardi Riva'i. Apt } \\
\text { (Health Office of } \\
\text { Pariaman) }\end{array}$ \\
\hline 10 & $\begin{array}{l}\text { Reproductive } \\
\text { Health and }\end{array}$ & $\begin{array}{l}\text { Meili Susiyetti, SKM } \\
\text { (BP2KB of Pariaman) }\end{array}$ \\
\hline
\end{tabular}

\begin{tabular}{|c|c|c|}
\hline $\mathrm{NO}$ & Material & Speaker \\
\hline & Family & \\
\hline & Planning & \\
\hline & Al-Qur'an & \\
\hline 11 & Recitation and & Zubir, S.Pd (LPTQ of \\
\hline 11 & Worship & Pariaman) \\
\hline & Training & \\
\hline 12 & $\begin{array}{l}\text { Household's } \\
\text { Problems and } \\
\text { the Solutions }\end{array}$ & $\begin{array}{l}\text { Drs. Fajaruddin (KUA of } \\
\text { Central Pariaman) }\end{array}$ \\
\hline
\end{tabular}

3) The schedule and time administration are well organized

From the interview with Firtrison Effendi, Secretary of the BP4, it is found that the administration of premarital counseling service for the prospective husband/wife in Pariaman is held from Friday to Sunday at the BP4 office. This finding shows that there has been a structured effort in providing premarital counseling service for the couple, so there is no such typical formality or careless administration done for the service.

4) The BP4 of Pariaman has already started performing their duties and functions

The variety of the materials, the qualifications of the counselors, and the schedule showed that the BP4 has taken serious steps and efforts in providing proper premarital counseling service for the prospective husband/wife. Moreover, the BP4 has made the effort to preserve marriage by opening wider consultation places for the married couples to solve their problems.

b. The roles of the BP4 in providing premarital counseling service for prospective husband/wife in Pesisir Selatan.

The types of the BP4 roles can be reviewed through the 
characteristics of the BP4 in Pesisir Selatan. The characteristics were obtained by interviewing the stakeholders and observing the research field.

1) The legal standing and position of the BP4 is unclear

The researcher considers the legal standing and position of the BP4 and the KUA as unclear. It can be seen from the unclearness of main duties and functions of both institutions. This finding is based on the interview with Afrizal, Section Head at Ministry of Religious Affairs in Pesisir Selatan, as shown below:

"In Tarusan sub-district of Pesisir Selatan, it was found there was no counselor who provided premarital counseling service. So, the one who provided the service was the head of the KUA. Besides, the staff of KUA was only one. Therefore, the duties and functions of the BP4 and KUA were largely performed by the head of KUA, with the help of one staff in that large sub-district area. "It is hard to imagine the great workload for that head of KUA and his staff in running those two institutions. Providing premarital counseling service and officiating weddings simultaneously. Not to mention the number of couples to be consulted and officiated in the sub-district."

In addition, he explained that several sub-districts in Pesisir Selatan, like Silaut and Luluang, had no staff. Overall, Pesisir Selatan n

Has a small number of officiants, counselors, and staff of
KUA as well as BP4. Generally, the premarital counseling service was not held in the KUA at all, but it was held in the BP4.

Moreover, the same situation was also explained by Arzen, head of KUA of IV Jurai, Pesisir Selatan, that the duties and functions of the officiant and counselor was the same. That is,

"In IV Jurai sub-district of Pesisir Selatan, the officiant who is supposed to only officiate the wedding also provides premarital counseling service. It means that the main duties and functions of the BP4 and KUA is the same. Although the structural job of the KUA and BP4 is different: the KUA works on wedding administration while the BP4 provides premarital counseling service, yet, the officiant, who should only work in the KUA, works in the BP4 too."

Therefore, it can be concluded that the management of the BP4 is not in order. Despite both KUA and BP4 having their own offices, their substantial main duties as well as functions remain unclear.

2) Imbalanced proportion between the population and the KUA and BP4 officers.

Lack of maximum provision of premarital counseling service in Pesisir Selatan is caused by the imbalanced ratio between the population and the KUA and BP4 officers. Afizal said, "In Tarusan sub-district, for example, there are approximately 35,000 residents, so when the heads of the KUA and BP4 poorly manage their works, all will mess up." 
It also indicates that there is imbalance in the KUA and BP4 officers' workloads because the number of population makes them difficult to handle their works properly. Consequently, lack of optimum service in premarital counseling must be evaluated as early as possible. Otherwise, the public will still assume that the KUA and BP4's works are carelessly done.

3) The provision of premarital counseling service for the prospective husband/wife is considered as institutional formality only.

The assumption is based on the finding in the field that premarital counseling service was done in a day. In terms of the length of time, the service had only one eighth of 24 hours. It means the premarital counseling service was only conducted for 3 hours. For example, in IV Jurai, the premarital counseling service started from 08.00 to 11.00 Western Indonesian time.

Furthermore, the administration of premarital counseling service is considered incidental. It is based on finding that the administration of the premarital counseling service had no regular day.

Arzen further explained that if the wedding was on Friday, the premarital counseling the service would be conducted on Monday at the earliest or on Thursday at the latest. This makes an impression that the service schedule was not organized and prepared very well.

4) Counselor's qualification as the premarital counseling service provider does not meet the standard yet.

The findings show the requirement for the counselor's qualification as the speaker in premarital counseling service was not up to the standard. The counselor in Pesisir Selatan was usually taken over by the head of the KUA, some community figure, such as religious or custom figures. It means that there was no individual who could fulfill the requirement and qualification as the counselor.

5) The materials of premarital counseling service is still general

Besides the lack of qualification of the counselor, the materials given to the prospective couple were not varied. The researcher found that generally the materials talked about religion only while other marriage-related materials were not provided. In this regard, the public would think the premarital counseling service is merely about "a test of reciting the Quran" or listening to the religious speeches, like those in Mosque.

6) The materials of premarital counseling service is included in the bulletin

All the materials of the premarital counseling service in Pesisir Selatan were covered on only a piece of premarital counseling bulletin. This shows that the counselor had no strong foundation in giving the service. This also tells that not much knowledge would be obtained by the prospective couple in going through their household until old age.

Therefore, it can be concluded that there was no "radical" understanding on the 
urgency of premarital counseling service to have the harmony of marriage for the family resilience in Pesisir Selatan, either for the prospective couple or for the administrator of premarital counseling service.

\section{CONCLUSIONS AND RECOMMENDATION}

Based on the results of the study, it can be concluded that:

1. The effectiveness rate of premarital counseling service on the harmony of marriage in West Sumatera reached as high as $3 \%$ in Pariaman, and as low as $0.1 \%$ in Pesisir Selatan.

2. The effectiveness rate of premarital counseling service on family resilience in West Sumatera was as high as $4.5 \%$ in Lima Puluh Kota and as low as $0.1 \%$ in Pesisir Selatan.

3. The roles of the board of marriage advisory and preservation (BP4) in West Sumatera were "very low". The BP4 which was considered established and intense in providing the premarital counseling service was the BP4 in Pariaman. The BP4 of other cities/districts did not play optimal roles.

The conclusions were based on the following: first, the low effectiveness of premarital counseling service in West Sumatera; second, the rate of divorcement in West Sumatera has not been declining; third, there was no "legal protection" for the existence of the board as well as its main duties and functions from the local government; fourth, the materials for premarital counseling service did not fulfill the needs of the prospective husband/wife; and fifth, there was no sufficient qualification of the counselor in providing the premarital counseling service.

\section{REFERENCES}

Kenedi, G. (2005). Model Konseling Pranikah Berorientasi Pengembangan Konsep Diri (Disertation). UPI Bandung, Bandung.

Larsen, A. S., \& Olson, D. H. (1989). Predicting marital satisfaction using prepare: A replication study. Journal of Marital and Family Therapy, 15(3), 311-322.

Murray, C. E. (2005). Prevention work: A professional responsibility for marriage and family counselors. The Family Journal, 13(1), 27-34.

Quthub, S. (2014). Tafsir fi Zhilalil Qur'an. Jakarta: Gema Insani.

Sugiyono. (2014). Metode Penelitian Kombinasi. Bandung: Alfabeta. 